\title{
The Impact of the Unofficial Cattle Business on the Household Welfare of Cattle Traders of the Border Towns of Cameroon and Nigeria
}

\author{
Saidou Baba Oumar ${ }^{1} \&$ Salihu Zummo Hayatudeen ${ }^{2}$ \\ ${ }^{1}$ Department of Economics \& Management, University of Buea, Buea, Cameroon \\ 2 Department of Economics, Modibbo Adama University of Technology, Yola, Nigeria \\ Correspondence: Saidou Baba Oumar, Department of Economics \& Management, University of Buea, Buea, \\ Cameroon. E-mail: saidoubo@gmail.com
}

Received: January 21, 2015

Accepted: March 4, 2015

Online Published: March 18, 2015

doi:10.5430/ijba.v6n2p146

URL: http://dx.doi.org/10.5430/ijba.v6n2p146

\begin{abstract}
This paper examines the impact of the unofficial cattle business on the household welfare of cattle traders of the border towns of Cameroon and Nigeria and relates that impact to the household access to basic needs or services of life such as income, employment, food, shelter, education, potable water, electricity, and health care that have been extensively used in the literature as indicators for the attainment of well-being and freedom from the yoke of poverty in the society. It uses primary and secondary data on the trade activities and employs descriptive as well as inferential techniques of data analysis to capture the objectives of the inquiry. The findings of the paper show that despite the unofficial character and unnoticed impact of the business by the governments of Cameroon and Nigeria, the traders who partake in the business acknowledge to have enhanced their living conditions with it. Poverty reduction being implicitly or explicitly cited as a strategy for household welfare improvement by the government in Cameroon and Nigeria, the paper recommends the enforcement, review and continuation of the existing poverty reduction programs irrespective of the leadership choice in the countries.
\end{abstract}

Keywords: trade, livestock, well-being, family, Cameroon, Nigeria

\section{Introduction}

Trade entails the exchange of goods and currencies between people, institutions or countries and it can be official or unofficial. With official trade between countries for instance, the volume and monetary value of all exported and imported items are adequately recorded in the balance of payment of the trading partners. However in the case of unofficial trade, it is difficult to arrive at a proper account of the volume and value of the goods and services traded between the partners. According to Uyenuga (1993), this form of unofficial cross-border business occurs in almost all sub-regions of the African continent at various degrees of intensity and is mostly influenced by factors such as weather or climatic conditions, socio-cultural and anthropological knots that are generally beyond the control of the trading partners. In the case of Cameroon and Nigeria, such factors influence and sustain livestock informal trade activities between the Northern Area of Cameroon (NAC) and Adamawa State of Nigeria (ASN).

Though Nigeria promotes formal cross-border trade, the practice of unofficial cross-border trade is still very significant in her economy due to factors such as differences in exchange rate, anthropological ties between trading countries, complexities of her trade licensing system, poor transportation and insecurity in the border areas that hinder the proper functioning of formal trade in the country (Balami, 2003). As the country prolongs the operation of unofficial businesses alongside the formal trade with her neighboring countries of Benin, Cameroon, Chad, and Niger Republic, such factors may continue to influence and sustain informal cattle trade activities in the country.

Yet, informal activities may not necessary be bad even though some of them are illegal based on local regulations. Therefore, there are costs and benefits associated with the minimization of informal practices. While constraints and restrictions still exist in the formal trade, any attempt to eliminate informal practices may lead to more costs than benefits. For instance Uche, Oumar, and Gazali (2003) argued that the cross-border cattle trade between NAC and ASN has contributed to increase the state revenue and economic growth over the years through cultural linkages involving people from Cameroon, Ethiopia, Somalia or Sudan and led to the growth in incomes of individual traders and their respective economies. Besides, Igene (2008) observed a high profit margin in the traded commodities, 
while Mwaniki (n.d) explained that this form of trade is perilous to internal economies of the trading partners but highly advantageous to individual traders who derive substantial benefits from it. Again, Holtzman (2009)'s study on cross-border trade between Ghana and Burkina-Faso showed that ethnicity plays a less dominant role in cross-border trade compared to a shared religion in particular Islam that plays a prominent role in facilitating it.

Once upon a time a large net exporter of food and animal products, Nigeria has now become an importer of some of these products mostly through informal cross-border trade with neighboring countries like Cameroon, Chad, and the Republic of Niger. It was noted that the value of cross-border cattle trade between Cameroon and Nigeria accounted for about $8 \%$ of Nigeria's total value of trade in 2007, thus making the income generated from it as one of the sources of income and food for the country (Iya, 2008). From the little documentation on Nigeria's cross-border trade activities, it is observed that the annual total volume of the foreign trade ranged between $5 \%$ and $10 \%$ in 2008 . Evidence and data from neighboring countries suggest that the actual value could be more than what was stated. Furthermore, the value of the unofficial cross-border cattle traffic for Nigeria was estimated at over $\$ 15$ billion ( $\$ 75$ million at $\$ 1=\$ 0.005$ as at 20/01/2015) in 2009 and if this estimate was officially recorded, the actual value of cross-border cattle business would have accounted for about $20 \%$ of Nigeria's total value of trade in that year (National Bureau of Statistics [NBS], 2010).

The unofficial cross-border cattle business between Cameroon and Nigeria existed before the demarcation of their current border limits because of the linkages between the two areas. The trade has become a permanent feature of the region but its contribution to the two governments still remains officially unnoticed because of its informal nature. The traded cattle are supplied to almost all parts of Nigeria to supplement the growing demand for meat consumption in the country but the gap between the aggregate demand and supply in the markets is still wide. Although agricultural products are the major commodities for cross-border trade, the most common commodities that cross the border; both formal and informal through the border exits of Cameroon to ASN, are cattle and food products. Yet, the cattle business engages a considerable portion of the population across borders but it is also observed that people in the border towns are poorer than their counterparts in the inner parts of the countries. Hence, there is need to investigate the socio-economic impact of the cattle trade on the border towns. Therefore, the main objective of this paper is to analyze the impact of the unofficial cattle business on the household welfare of cattle traders of the border towns of Cameroon and Nigeria. Other specific objectives of the paper are:

1. To examine the socio-economic characteristics of cattle traders,

2. To examine the accessibility of cattle traders to basic needs or services of life,

3. To determine the impact the cattle business on the lives of traders, and

4. To suggest ways of mitigating poverty for welfare enhancement in the countries.

There is very little documentation relating to Nigeria's cross-border cattle trade. This is mainly because cross-border activities between Nigeria and its neighbors are mostly informal and so reliable secondary data do not exist to reflect the actual situation. However, the few studies that examined the phenomenon emphasized less on the access of participants to basic needs or services of life and the welfare of their households. This paper relates the welfare of the households to the trade and explains how the trade mitigates the effects of poverty in the study area.

The determinants of household welfare can be classified into income and non-income indicators. The World Bank (2001) used income, education, self-esteem, livelihood, and sustainability as indicators that promote the well-being of the household and the community in harmony with their needs and aspirations. Mukherjee and Benson (2003), and Okojie (2002) argued that per capita expenditure is the major determinant of welfare of a household. Yet for Siddiqui (2001), the welfare of the household depends on its capability of having access to food, shelter, health care, and education based on the level of income it earns. Dolgoff (2010) substantiates by adding the access to social influence, legal protections, or personal fulfillment that are not economic terms because general household welfare is not solely an economic phenomenon. Therefore, household welfare is a broad concept referring to a state of living of an individual or group in a desirable relationship with the total environment including both the social and economic aspects of the unit. The concept of household welfare implies the welfare of man, his family and his community. However, this paper assesses the welfare of the household against the accessibility of cattle business households to basic needs or services such as income, employment, food, shelter, potable drinking water, electricity, and health care which aim at alleviating distress and poverty in the society. Consequently, the rest of the paper is organized as follows. Section 2 explores works related to the subject matter of the paper. Section 3 explains the methodology. Section 4 focuses attention on data analysis and discussion of results, while section 5 gives the conclusion and recommendations of the paper. 


\section{Review of Literature}

The informal sector is that part of an economy that is not taxed, monitored by government or included in any gross national product (GNP), unlike the formal sector. In developing countries about $70 \%$ of the potential working population earns a living through informal sector (Bromley, 1978). Perberdy (2002) posits that the informal sector forms a substantial percentage of economic activities in the African economy, even though the trade records are entirely unavailable. Hart (1973) argues that the informal sector is mainly characterized by the reliance on indigenous resources, small scale operation, labor intensive and adopted technology, and low receipts of income or skills required outside the school system. Furthermore, activities of this sector are not captured in official records and usually they have no formal income remunerations. Similarly, Edward (2008) maintains that the informal sector is nothing more than heterogeneous enterprises outside any contractual arrangement or as pointed by Aryeetey (2009) enterprises without neither official status nor any social security by the government and involved in smuggling. In short, Nduru (2004) concludes that the informal trade takes different forms and is known under different names (unrecorded trade; illegal trade; unofficial trade; trade subject to over and under invoicing, smuggling, hoarding). It is best characterized by its non-inclusion in the national accounts of a country or region in terms of its domestic and international transactions.

Cross-border trade is a feature of regional trade and occupies a central position in the international trade theories as explained by most economists. In the course of defeating the mercantilist school of thoughts of the recently acclaimed technological theories, the key element in all is the principle of comparative advantage which stipulates that no matter how strong or absolutely weak a country is, it can still maximize the profit available to it by concentrating on those activities in which it is relatively more powerful and hiring the services of specialist in those activities in which it is relatively weak (Thom, 1971). In trying to obtain information on the volume and value of the unrecorded trade flows between Kenya and Uganda, Ackello-Ogutu and Echessah (1997) revealed that Kenya has a comparative advantage in manufacturing and processing goods such as hardware, textile, beverages, wheat, and flour over Uganda, whereas Uganda's comparative advantage over Kenya largely rests on unprocessed agricultural commodities such as maize, beans and fish. Within the same theoretical underpinning, Macedo (1987) shows that the cross-border trade between Nigeria and its neighbors can be understood within the context of the relative-factor-availability theory for the trade is being facilitated by the relative abundance of livestock and gum Arabic in Niger, Chad and Cameroon and the relative abundance of petroleum products and manufactured goods in Nigeria as also upheld in Balami (2007). By examining the dynamics of informal livestock cross-border trade between Cameroon and Nigeria; Hayatudeen, Oumar, and Gazali (2005) revealed that on the average more than 50\% of the livestock, in particular cattle, being traded in ASN come from Cameroon. They also argued that differences in factor endowment between the two countries as well as socio-cultural ties greatly influence the trade sustainability in the sub region.

While analyzing the role of informal cross-border trade in Myanmar, Winston (2009) showed that cross-border trade activities have more positive effect on income levels amongst men than women. In term of age, the channels of younger respondents having a higher income are over four times higher than that of older respondents. He further revealed that on the average, most households involved in small business experience negative effect of the trade because of the increase in the prices of goods at the border areas. Conversely, Marin and Verdier (2014) and Mayer, Melitz, and Ottaviano (2011) assessed the economic gains of informal cross-border trade between Kenya and Uganda and found that the economic gains from informal trade between the two countries include job creation, provision of agriculture and industrial goods that would otherwise be unavailable and reduction of food shortage conditions. Yet, the lack of working capital was singled as the largest barrier to business expansion beside high interest rates, bureaucratic bottlenecks such as licenses, poor infrastructure, and increased corruption at the border. The authors concluded that trade liberalization through regional cooperation initiatives such as harmonization of domestic food policies, relaxation of trade barriers, and government willingness to enforce these initiatives would enhance the large existing trade potential between Kenya and Uganda.

In the horn of Africa, Azeze (2010) studied cross-border cattle trade and food security issues and found that cross-border trade finances grain imports with a considerable impact on food security in the region. He further argued that most of the herders surfer as a result of downward trends in cross-border cattle trade in the region. In the same region, Hussein (2010) examined the role of cross-border cattle trade on the livelihood systems of pastoral and agro-pastoral population revealing that export trade is supported by a network of regional cross-border trade, where the interior range lands are linked to the ports through a series of clan-based corridors. He also argued that the regional cross-border cattle trade network supports about 17 million people in the horn of Africa including livestock producers, traders, and other groups such as trekkers, fodder traders, brokers and middlemen who directly or indirectly derive their entitlements from cattle production and trade. 
As regards intra-regional trade, Holtzman (2009) analyzed the informal cross-border trade conditions in Ghana and Burkina-Faso for livestock, kola nut and onions listing four main problems that have negative impact on the livestock business between the two countries. These problems are: prohibitive import duties, bribery and corruption, non-commercialization of livestock producers, and exchange rate issues; adding that the first and second problems encourage cross-border smuggling. Finally, Nkendah (2010) in a study on the volume and value of unrecorded cross-border trade flows on agricultural commodities between Cameroon and its Communauté Economique et Monetaire de l'Afrique Centrale (CEMAC) neighbors explained that in 2008 over 155 thousand tons of agricultural and horticultural commodities were officially shipped from Cameroon to its CEMAC neighbors for an estimated 38 billion FCFA ( $\$ 76$ million at 1FCFA $=\$ 0.002$ as at 20/01/2015), representing $4 \%$ of the GDP in Cameroon. The comparison in relative terms indicates that informal trade between the trading parties represents $96 \%$ of the transactions mainly involving agricultural and horticultural commodities. In a country specific analysis, Iya (2008) collected data in four cattle markets in ASN to assess the effects of informal cross-border cattle trade on the economy of ASN, and found that the revenue accruing to the government increased tremendously, while the income of traders increased by $40 \%$.

A critical examination of previous studies reviewed shows the extent to which efforts have been invested in identifying and explaining the advantages and disadvantages of the unofficial business across international boundaries. According to the authors, the specific gains of the unofficial business ranged from it being a source of employment and spring board for income generation to many people, a means of encouraging social cohesion between people living across the borders to it being explained by some trade theories. Conversely, the particular disadvantages associated with the business covered a wide range of socio-economic problems such as the lack of reliable official records of the terms of trade between trading countries, over-reliance of actors on indigenous business practices, exchange rates bureaucracies breeding the growth of parallel foreign exchange market, and corruption. Beside these important elements in explaining the unofficial business across international borders from the macro-economic perspective, this study undertakes the analysis on the micro-economic perspective to understand the weight of the business vis à vis the welfare of households partaking in its activities.

\section{Methodology}

This section explains the methodology used in achieving the objectives of the inquiry. It starts with a description of the study area before discussing the data, instruments of data collection, sample size and sampling technique, and techniques of data analysis.

\subsection{Description of the Study Area}

This study covers the livestock border markets and control posts in NAC and ASN. In NAC the markets concerned are Adoumri, Garoua, Mokolo, and Ngaoundéré, while in ASN the targeted cattle markets are Ganye, Konkol, Madagali, Mubi, Ngurore, and Shigari. These localities are the main cattle supply centers in the study area. ASN covers an area of about 42159 square kilometers $\left(\mathrm{Km}^{2}\right)$ and is a combination of former Adamawa Province (AP) with some part of Sardauna Province (SP). It is inhabited by the Bura, Bwatiye, Chamba, Fali, Fulani, Gira, Gude, Hausa, Higgi, Kanakuru, Kilba, Lunguda, Margi, Mbulo, Nzanyi, and Yungur people. Each social group has its own language but Fulfulde and Hausa languages are lingua-franca in the state. The communities in ASN earn a living through public service work, farming, rearing of animals, fishing and trading activities (Sa'ad, 1979). The state has an estimated population of 3.2 million people (National Population Commission [NPC], 2006). The climate of the area is dominated by the same movement of wind system from November to February, and then from March to June hot air dominates the wind system with an average temperature of about $35^{\circ} \mathrm{C}$ and a rainfall average of 959 millimeters $(\mathrm{mm})$ in the northern parts and $987 \mathrm{~mm}$ in the southern zone (Sa'ad, 1979). Conversely, the NAC stretches over an area of $164054 \mathrm{Km}^{2}$ (Carte Administrative du Cameroun [CAC], 2008 cited in Institut National de la Statistique [INS], 2013:86-87). The total population of NAC is about 7.25 million people (INS, 2013:85). The people in NAC share common religion and culture with the people in ASN. The area is inhabited mostly by the Fali, Fulani, Nzanyi, Shoa-Arabs people among others and their major occupations include farming, rearing of animals and trading (Sa'ad, 1979). The climatic condition of the area is dominated by the movement of wind system from November to March; generally conducive for livestock breeding with an average temperature of about $32.50^{\circ} \mathrm{C}$ and an average rainfall of $1011 \mathrm{~mm}$ (Sa'ad, 1979).

\subsection{Data and Techniques of Analysis}

Both primary and secondary data were used to capture the objectives of the paper. Primary data were generated from surveys, interviews, and personal observations. Secondary data were obtained from INS for Cameroon, National Bureau of Statistics (NBS), and NPC for Nigeria. Purposive sampling and random sampling techniques were used to organize the data. To obtain a reasonable set of data, 4 markets in Cameroon were purposively selected for being main cattle supplying centers in NAC. Also 6 out of the 21 local government areas were purposively selected in ASN 
for their border proximity and possession of larger cattle markets compared to other markets in the state. Furthermore structured interviews were randomly conducted beside 20 cattle traders in the 10 markets, giving a total of 200 respondents drawn from both NAC and ASN. The markets visited were: Adoumri, Garoua, Mokolo and Ngouandere in Cameroon and Ganye, Konkol, Madagali, Mubi, Ngurore, and Shigari in Nigeria. In order to capture the objectives of the paper, both the descriptive and inferential techniques of data analysis were utilized. The descriptive method employed tables, averages, and simple percentages to interpret the data. Conversely, the inferential approach used the EXCEL software package of data analysis to compute the theoretical (expected) scores from the actual (observed) scores of the sample and the Chi-square $\left(\chi^{2}\right)$ statistic for the testing of stated hypotheses at some given level of significance. The number of traders interviewed in each market constitutes $10 \%$ of the sample drawn and this information is summarized in Table 1.

Table 1. Sample elements from the border towns of Cameroon and Nigeria

\begin{tabular}{|c|c|c|c|}
\hline Area & Market & Trader Interviewed & Percentage $(\%)$ \\
\hline \multirow{3}{*}{ Cameroon } & Adoumri & 20 & 10 \\
\hline & Garoua & 20 & 10 \\
\hline & Mokolo & 20 & 10 \\
\hline \multirow{8}{*}{ Nigeria } & Ngaoundéré & 20 & 10 \\
\hline & Ganye & 20 & 10 \\
\hline & Konkol & 20 & 10 \\
\hline & Madagali & 20 & 10 \\
\hline & Mubi & 20 & 10 \\
\hline & Ngurore & 20 & 10 \\
\hline & Shigari & 20 & 10 \\
\hline & Total & 200 & 100 \\
\hline
\end{tabular}

Source: Authors

\section{Data Analysis and Discussion of Results}

This section deals with data analysis and discussion of results. It attempts to address the specific objectives of the investigation one after the other under separate headings.

\subsection{Socio-economic Characteristics of Cross-border Cattle Traders}

Table 2 presents a summary of selected socio-economic characteristics of the respondents. It shows that the mean age of cattle traders is 45 years old, average number of years of experience for the traders in the business is about 7 years long, and mean size of households is 7 people. These demographic statistics can be attributed to the fact that both Cameroon and Nigeria are characterized by more young people than old ones given their large base pyramid of ages of the population; traders are risk averse to venture into new activities for a livelihood; having a large family procures honor and security against old age, respectively in the study area. All other things being equal, it reveals that the mean income of households is $\$ 98000$ (\$490) per month or $\$ 3266.66(\$ 16.33)$ per day $(98000 \div 30=$ 3266.66) for a typical cattle trading household, which in turn translates to $\$ 466.66$ (\$2.33) per person per day $(3266.66 \div 7=466.66)$ due to the profitability of the business in the study area. Also, it discloses that the average amount to disburse for transporting a medium size cattle from a supply center to a destination market approximates $\$ 2208$ (\$11.04). Furthermore, it explains that 4\% of the respondents are female and 96\% are male because in most rural and semi-urban households of the border towns in the study area, household decision making is the prerogative of men. Therefore in any random selection for studies involving household decision making, the proportion of males' representation is likely to be higher than that of females. As regards the educational background of the respondents, it indicates that 42\% have Quranic education, 21\% have completed primary education, 19.5\% have achieved secondary education, and $17.5 \%$ have attained tertiary education. The relatively higher percentage of Quranic education in the study area is connected to the flexibility in the study mode of the system, low costs of study and the willingness of the people to understand their religion. About the main occupation of the respondents, it reports that $84 \%$ of the respondents primarily depend on the informal cross-border cattle trade for a living, while the remaining $16 \%$ are occupied in some sort of activities within the formal sector in the area owing to their proximity to the border towns through which transit the informal trade activities and the lack of lucrative alternative job opportunities to explore. Furthermore, it shows that over $80 \%$ of the traders obtain their foreign exchange through parallel markets due to the bureaucratic and long documentation procedures of the official foreign exchange market, which people try shunning for sake of reduction of transaction costs and saving of time. A recap of the discussion is given in Table 2. 
Table 2. Summary of selected socio-economic characteristics of the respondents

\begin{tabular}{lccc}
\hline Quantitative Variable & Maximum & Mean & Minimum \\
\hline Age (Years) & 75 & 45 & 19 \\
Experience (Years) & 10 & 7 & 5 \\
Household Size (People) & 20 & 7 & 1 \\
Household Income (\#) & 500000 & 98000 & 50000 \\
Transportation Costs ( & 5475 & 2208 & 1163 \\
\hline Qualitative variable & Options & Frequency & Percentage (\%) \\
\cline { 2 - 4 } Gender & Female & 8 & 4 \\
& Male & 192 & 96 \\
\cline { 2 - 4 } & Quranic & 84 & 42 \\
Education & Primary & 42 & 21 \\
& Secondary & 39 & 19.5 \\
& Tertiary & 35 & 17.5 \\
\cline { 2 - 4 } Main Occupation & Farming & 24 & 12 \\
& Schooling & 5 & 2.5 \\
Foreign Exchange Access & Trading & 168 & 84 \\
\hline
\end{tabular}

Source: Authors

\subsection{Accessibility of Cattle Traders to Basic Needs or Services of Life}

Table 3 shows the estimate of a typical cattle business household daily expenditure in the study area. It reveals that the highest average amount of money spent for daily consumption was recorded in Madagali as \$5112 (\$25.56) per day and the least amount of $\$ 1068$ (\$5.34) per day was registered in Ganye. As a result, an average cattle business household in the study area spends about $\$ 2378.20$ (\$11.89) per day for its up-keep. This implies a daily consumption expenditure of $\$ 339.74$ (\$1.69) per person for a household. Compared to the daily per capita income of $\$ 466.66$ (\$2.33), it follows that a member of a household is capable of saving \$126.92 (\$0.63) per day (466.66 $339.74=126.92)$ or $\$ 3807.60(\$ 19.03)$ per month $(126.92 * 30=3807.60)$, which is often utilized to acquire household assets and equipment to enhance the welfare of the household in the study area.

Table 3. Estimate of a typical cattle business household daily expenditure

\begin{tabular}{|c|c|c|}
\hline Market & Amount $(\mathrm{N})$ & Percentage $(\%)$ \\
\hline Adoumri & 1497 & 6.29 \\
\hline Garoua & 1391 & 5.84 \\
\hline Mokolo & 1975 & 8.30 \\
\hline Ngaoundéré & 2321 & 9.75 \\
\hline Ganye & 1068 & 4. 49 \\
\hline Konkol & 1726 & 7.25 \\
\hline Madagali & 5112 & 21.49 \\
\hline Mubi & 1428 & 6.00 \\
\hline Ngurore & 3674 & 15.44 \\
\hline Shigari & 3590 & 15.09 \\
\hline Total & 23782 & 100 \\
\hline
\end{tabular}

Source: Authors

Table 4 displays the total monetary value of assets in a typical cattle business household in the study area. It explains that the highest average money value of household assets was recorded in Garoua as $\$ 2309500(\$ 11547.5)$ or $24.81 \%$ of the gross total and the least was observed in Konkol as $\$ 241000$ ( $\$ 1205)$ or $2.58 \%$ of the gross total. On the average, the worth of household assets for a typical cattle trading household in the study area translates to $\$ 930$ 
586 ( $\$ 4652.93)$. The profitability of the business in the study area explains the ability of households to accumulate assets of more than $\$ 500000$ (\$2500).

Table 4. Total monetary value of a typical cattle business household assets

\begin{tabular}{|c|c|c|}
\hline Market & Asset Value ( $\mathbb{N})$ & Percentage (\%) \\
\hline Adoumri & 1871150 & 20.11 \\
\hline Garoua & 2309500 & 24.81 \\
\hline Mokolo & 1302500 & 13.99 \\
\hline Ngaoundéré & 439450 & 4.72 \\
\hline Ganye & 275611 & 2.96 \\
\hline Konkol & 241000 & 2.58 \\
\hline Madagali & 842500 & 9.05 \\
\hline Mubi & 485000 & 5.21 \\
\hline Ngurore & 495900 & 5.32 \\
\hline Shigari & 1043250 & 11.21 \\
\hline Total & 9305861 & 100 \\
\hline
\end{tabular}

Source: Authors

Table 5 captures the aspect of the ownership of houses by the cattle business traders in the study area. It shows that $70 \%$ of the cattle traders own house in Ganye, $85 \%$ in Mubi and Ngurore, $90 \%$ in Adoumi, Garoua, and Shigari, 95\% in and Ngaoundéré and Konkol, and all of them possess a house in Mokolo and Madagali. On the aggregate, an average of only $10 \%$ of the cattle traders in the study does not own a house. This may be explained by the savings opportunity the business offers to its actors since the daily per capita income exceeds the daily consumption expenditure, and the general tendency of people in the study area to guarantee their progeny a family house on which to fall back in periods of difficulties in accommodation.

Table 5. Ownership of a house by cattle business traders

\begin{tabular}{lcc}
\hline Market & Owning & Not Owning \\
\hline Adoumri & $18(90)$ & $2(10)$ \\
Garoua & $18(90)$ & $2(10)$ \\
Mokolo & $20(100)$ & 0 \\
Ngaoundéré & $19(95)$ & $1(5)$ \\
Ganye & $14(70)$ & $6(30)$ \\
Konkol & $19(95)$ & $1(5)$ \\
Madagali & $20(100)$ & 0 \\
Mubi & $17(85)$ & $3(15)$ \\
Ngurore & $17(85)$ & $3(15)$ \\
Shigari & $18(90)$ & $2(10)$ \\
\hline Percentage Average (\%) & 90 & 10 \\
\hline
\end{tabular}

Source: Authors

Figures in brackets represent percentages.

Table 6 shows the proportion of the cattle business households with access to pipe-borne water in the study area. It reveals that more than $50 \%$ of the households have access to pipe-borne water in Garoua and Ngaoundéré. Just $50 \%$ of the households enjoy potable drinking water in Adoumri and Ngurore, while in the rest of the localities the access rate of households to pipe-borne water is below $50 \%$. On the average, only $42.5 \%$ of the households have access to pipe-borne water in the study area. The remaining $57.5 \%$ of the households manage water collected from boreholes or wells to undertake their domestic activities. The percentage of below $50 \%$ of the households having access to potable drinking water in the study area is reflective of the general situation of poor access of people to basic utilities affecting the rural and semi-urban areas in developing countries. 
Table 6. Access of cattle business households to pipe-borne water

\begin{tabular}{lcc}
\hline Market & Pipe-borne Water & Non-pipe Borne Water \\
\hline Adoumri & $10(50)$ & $10(50)$ \\
Garoua & $11(55)$ & $9(45)$ \\
Mokolo & $9(45)$ & $11(55)$ \\
Ngaoundéré & $16(80)$ & $4(20)$ \\
Ganye & $8(40)$ & $12(60)$ \\
Konkol & $5(25)$ & $15(75)$ \\
Madagali & $5(25)$ & $15(75)$ \\
Mubi & $5(25)$ & $15(75)$ \\
Ngurore & $10(50)$ & $10(50)$ \\
Shigari & $6(30)$ & $14(70)$ \\
\hline Percentage Average (\%) & 42.5 & 57.5 \\
\hline
\end{tabular}

Source: Authors

Figures in brackets represent percentages.

Table 7 displays the proportion of the cattle business households with access to electricity in the study area. It shows than more than $65 \%$ of the households in the border towns have access to electricity through the connection to the national electricity supply network of the countries or operation of personal power supply generators as opposed to Adoumri, where only $50 \%$ of the households have access to electricity. On the average, $89 \%$ of the households enjoy electricity supply in the study area. The remaining $11 \%$ of the households without access to electricity depend on candles or bush lamps to light their houses. The high percentage rate of access of households to electricity is associated with the execution of the rural electrification programs embraced by the government in both Cameroon and Nigeria.

Table 7. Access of cattle business households to electricity

\begin{tabular}{lcc}
\hline Market & Electricity & Others \\
\hline Adoumri & $10(50)$ & $10(50)$ \\
Garoua & $18(90)$ & $2(10)$ \\
Mokolo & $20(100)$ & $0(0)$ \\
Ngaoundéré & $17(85)$ & $3(15)$ \\
Ganye & $14(70)$ & $6(30)$ \\
Konkol & $19(95)$ & $1(5)$ \\
Madagali & $20(100)$ & 0 \\
Mubi & $18(90)$ & $2(10)$ \\
Ngurore & $19(95)$ & $1(5)$ \\
Shigari & $17(85)$ & $3(15)$ \\
\hline Percentage Average $(\%)$ & 89 & 11 \\
\hline
\end{tabular}

Source: Authors

Figures in brackets represent percentages.

Table 8 shows the proportion of the cattle business households with access to health care services in the study areas. It reveals that at least $70 \%$ of the households in each border town have easy access to health care services in the study area. On the average more than $80 \%$ of the households enjoy easy access to health care services with only $14 \%$ expressing difficulty in accessing the services in the study area. This situation is reflective of the reaction and commitment of the government in Cameroon and Nigeria to build more low costs health centers in rural and semi-urban localities to offer a collective response to the fight against pandemic diseases. 
Table 8. Access of cattle business households to health care services

\begin{tabular}{|c|c|c|}
\hline Market & Easy Access & Difficult Access \\
\hline Adoumri & $19 \quad(95)$ & $1 \quad(5)$ \\
\hline Garoua & $18 \quad(90)$ & $2 \quad(10)$ \\
\hline Mokolo & $18 \quad(90)$ & $2 \quad(10)$ \\
\hline Ngaoundéré & $16 \quad(80)$ & $4 \quad(20)$ \\
\hline Ganye & $14 \quad(70)$ & $6 \quad(30)$ \\
\hline Konkol & $20 \quad(100)$ & 0 \\
\hline Madagali & $18 \quad(90)$ & $2 \quad(10)$ \\
\hline Mubi & $17 \quad(85)$ & $3 \quad(15)$ \\
\hline Ngurore & $17 \quad(85)$ & $3 \quad(15)$ \\
\hline Shigari & $15 \quad(75)$ & $5 \quad(25)$ \\
\hline Percentage Average (\%) & 86 & 14 \\
\hline
\end{tabular}

Source: Authors

Figures in brackets represent percentages.

\subsection{Impact of the Cattle Business on the Lives of Cattle Traders}

Table 9 displays the responses of the cattle business households on the influence of the business in reducing poverty in the study area. It discloses that at least $85 \%$ of the households in each border town agree with the ability of the cattle trade to reduce the poverty of households in the study area. On the average, $94 \%$ of the households are of the view that the cattle business is influential in reducing their level of poverty in that it has improved their lives in terms of feeding, income generation, employment opportunity, shelter, and access to services such potable drinking water, electricity, education, and health care. The remaining $6 \%$ of the households claim to have witnessed no improvement in their lives as a strategy of hiding their well-being and happiness to unknown people.

Table 9. Influence of cattle business in reducing poverty of households

\begin{tabular}{lccc}
\hline & \multicolumn{2}{c}{ Responses } & Total \\
\cline { 2 - 3 } Market & Yes & No & $20(10)$ \\
Adoumri & $20(100)$ & 0 & $20(10)$ \\
Garoua & $18(90)$ & $2(10)$ & $20(10)$ \\
Mokolo & $20(100)$ & 0 & $20(10)$ \\
Ngaoundéré & $17(85)$ & $3(15)$ & $20(10)$ \\
Ganye & $19(95)$ & $1(5)$ & $20(10)$ \\
Konkol & $20(100)$ & 0 & $20(10)$ \\
Madagali & $20(100)$ & 0 & $20(10)$ \\
Mubi & $19(95)$ & $1(5)$ & $20(10)$ \\
Ngurore & $20(100)$ & 0 & $20(10)$ \\
Shigari & $15(75)$ & $5(25)$ & $200(100)$ \\
\hline Total & $188(94)$ & $12(6)$ & \\
\hline
\end{tabular}

Source: Authors

Figures in brackets represent percentages.

To test the impact of the unofficial cattle business on the household welfare of cattle traders using the $\chi^{2}$ statistic, traders were asked to give a general assessment about whether or not the trade has spared them from poverty and advanced their conditions of life. The responses of the traders as presented in Table 9 are the actual (Observed) scores of the sample on that assessment in the study area. Based on the responses of the traders, two hypotheses are formulated as follows.

Null hypothesis: $\mathrm{H}_{0}$ : The unofficial cattle business has no significant impact on the household welfare of cattle traders of the border towns of Cameroon and Nigeria.

Alternative hypothesis: $\mathrm{H}_{1}$ : The unofficial cattle business has significant impact on the household welfare of cattle traders of the border towns of Cameroon and Nigeria. 
The mathematical formulae required to undertake the $\chi^{2}$ test are specified in the following equations. The $\chi^{2}$ statistic formula that transforms the sample scores into a test statistic is given in equation (1). The formula for computing the corresponding theoretical (Expected) scores based on the actual (Observed) scores obtained from the responses of the traders is represented in equation (2). The formula for the degree of freedom $(D f)$ to consider in the running of the $\chi^{2}$ test is given in equation (3), while the level of significance for the test is set at $\alpha=5 \%$.

$$
\begin{gathered}
\chi^{2}=\frac{\sum\left(A_{i}-T_{i}\right)^{2}}{T_{i}} \\
T_{i}=\frac{\left(\sum_{r i}\right)\left(\sum_{c i}\right)}{N} \\
D f=(\mathrm{R}-1) *(\mathrm{C}-1)
\end{gathered}
$$

A $i$ : Actual score of category $\mathrm{i}$

$\mathrm{T}_{i}$ : Theoretical score of category $i$

$\Sigma_{r i}$ : Summation of row $i$

$\Sigma_{c i}$ : Summation of column i

$\mathrm{N}$ : Total number of sample scores

R: Number of rows

C: Number of columns

To compute the $\chi^{2}$ statistic, contingency tables for the actual and theoretical scores of the sample are constructed and then pooled together in a single $\chi^{2}$ computation contingency table (See Appendices). The theoretical scores of the sample are computed in EXCEL by applying the formula in equation (2), while the calculation of the $\chi^{2}$ statistic is done by applying the requirements of equation (1) and equation (3). The decision rule for the $\chi^{2}$ statistic is that the null hypothesis is rejected if the value of the $\chi_{s}^{2}$-Stat (Computed $\chi^{2}$ ) is greater than the value of the $\chi_{t}^{2}$-Crit (Critical $\chi^{2}$ value obtained from the $\chi^{2}$ distribution table), that is, $\chi_{s}^{2}>\chi_{t}^{2}$ at a given $D f$. In contrast, the null hypothesis is accepted if the value of the $\chi_{s}^{2}$-Stat is less than or equal to the value of the $\chi_{t}^{2}$-Crit, that is, $\chi_{s}^{2} \leq \chi_{t}^{2}$ at a given $D f$. By applying equation (1) and equation (3) for the test, it follows from Table 10 that at $\alpha=5 \%$ with $D f=(10-1)^{*}(2-1)$ $=(9)^{*}(1)=9, \chi_{s}^{2}$-Stat $=22.695$ and $\chi_{t}^{2}$-Crit $=16.919$. Consequently, since the $\chi_{s}^{2}$-Stat is greater than the $\chi_{t}^{2}-$ Crit, that is, $\chi_{s}^{2}>\chi_{t}^{2}(22.695>16.919)$, the null hypothesis that the unofficial cattle business has no impact on the household welfare of cattle traders of the borders towns of Cameroon and Nigeria household is rejected, implying that it significantly impacts on the household welfare of cattle traders in the study area.

Table 10. Summary of outcome of Chi-square Statistic Test

\begin{tabular}{lc}
\hline Parameter & Entry \\
\hline $\mathrm{H}_{0}$ & No Impact of Unofficial Cattle Business on Household Welfare of Cattle Traders \\
$\mathrm{H}_{1}$ & Impact of Unofficial Cattle Business on Household Welfare of Cattle Traders \\
Control Variable $(\mathrm{CV})$ & Cattle Market Centers \\
Category for CV & Adoumri, Garoua, Mokolo, Ngaoundéré, Ganye, Konkol, Madagali, Mubi, Ngurore, Shigari \\
Decision Variable $(\mathrm{DV})$ & Responses \\
Category for DV & Yes, No \\
Row for CV & 10 \\
Column for DV & 2 \\
Degree of Freedom $(D f)$ & 9 \\
Significance Level $(\alpha \%)$ & 5 \\
Sample Size & 200 \\
$\mathrm{X}_{\mathrm{s}}{ }^{2}$-Stat & 22.695 \\
$\mathrm{X}_{\mathrm{t}}{ }^{2}$-Crit & 16.919 \\
Decision Rule & $\mathrm{X}_{\mathrm{s}}^{2}>\mathrm{X}_{\mathrm{t}}^{2}$ \\
\hline Decision & ${\text { Reject } \mathrm{H}_{0}}$ \\
\hline
\end{tabular}

Source: Estimation 


\section{Conclusion and Recommendations}

Drawing from the analysis of data, it is observed that majority of the cattle traders; except in Ngaoundéré; were employed in the informal sector, implying that the unofficial cattle trade is a major source of employment and source of income to people in the study area. Since priority is normally given to ensuring the contributions of the trade sector to the economic development, its contribution to poverty reduction is highly acknowledged by the cattle traders in the study area. It was found that the average money value of the household assets owned by the cattle traders was $\$ 930586$ (\$4652.93) and most of them live in their personal houses. Though on the average less than $50 \%$ of the cattle business households have access to pipe-borne water, except in Adoumri, Garoua, Ngaoundéré, and Ngurore in the study area, this is not a strange phenomenon affecting the rural and semi-urban areas in the developing countries. Furthermore, it was observed that a greater proportion of the cattle business households have electricity in their houses and easy health care services in the order towns of the study area. Above all a considerable fraction of the cattle business households recognized an improvement in their lives since they joined the business, especially in terms of in terms of feeding, income generation, employment opportunity, shelter, and access to services such potable drinking water, electricity, education, and health care; thus implying that the unofficial cattle business has the potentials of reducing the poverty of people in the study area. As a result of these, the following recommendations are advanced. One, in order for the unofficial cattle trade to grow and contribute to the poverty alleviation of more people, a pro-poor approach through which more disadvantaged people are allowed to participate is imperative. Two, the existing poverty alleviation schemes should be executed, revised, and continued irrespective of the whims and caprices of the leadership in the countries.

\section{References}

Ackello-Ogutu, C., \& Echessah, P. N. (1997). Unrecorded Cross-border Trade between Kenya and Uganda: Implications for Food Security, Technical Paper No.59, AFR/SD and REDSO/ESA, SD Publication Series, United States Agency for International Development (USAID), Africa Bureau. Retrieved 11 February 2015, from

http://www.google.com/url?....unrecorded-cross-border-trade-between-kenya-and-uganda-implications-for-food -security\%2....bv.85761416,d.ZWU

Aryeetey, E. (2009). The Informal Economy, Economic Growth and Poverty in Saharan Africa. A Paper Prepared for AERC Project Workshop on "Understanding Links between Growth and Poverty Reduction in Africa". Retrieved 20 January 2015, from dspace.africaportal.org/jpub/. ..Aryeetey_Informality.pdf? 1

Azeze, A. (2010). A Research Report of the Broadening Access to Market and Input Systems. Collaborative Research Support Program on Cross-border Cattle Trade and Food Security in the Horn of Africa, Submitted to USAID.

Balami, D. H. (2003). Cross-border Trade between Nigeria and her Neighbours: A Case Study of Nigeria and Tchad. A Report Submitted to Network on Cross-border Trade between Nigeria and her Neighbours, Paris: Laboratoire d'Analyse Régionale et d' Expertise Sociale (LARES).

Balami, D.H. (2007). Cross-border Trade between Nigeria and her Neighbours. A Report Submitted to Network on Cross-border Trade, Paris: LARES.

Bromley, R. (1978). The Urban Informal Sector: Why is it Worth Discussing?, World Development, 6(9/10), 1033-1039.

Carte Administrative du Cameroon [CAC], 2008.

Dolgoff, R. (2010). Understanding Social Welfare (4th ed.). London: Oxford University Press.

Edward, A. (2008). Growth Incidence Analysis for Welfare Indicators: Evidence from Ghana and Uganda, Background Paper for the Chronic Poverty Report 2008-09, Chronic Poverty Research Centre (CPRC). $\begin{array}{llll}\text { Retrieved } 20 & \text { January } & 2015, & \text { from }\end{array}$ www.chronicpoverty.org/uploads/publication_files/CPR2_Background_Paper_Anderson.pdf

Hart, K. B. (1973). Informal Income Opportunities and Urban Unemployment in Ghana. Journal of Modern African Studies, 11(1), 61-89.

Hayatudeen, S.Z., Oumar, S.B., \& Gazali, K.A.Y. (2005). The Dynamics of Informal Livestock Cross-border Trade between Nigeria and Cameroon. Maiduguri Journal of Arts and Social Sciences, (1).

Holtzman, J. (2009). Livestock Marketing along the Burkina-Faso and Ghana Corridor. Report Submitted to USAID/Ghana.

Hussein, M. D. (2010). The Dynamics of Cattle Trading in Northern Kenya and Southern Ethiopia: The Role of Trust and Social Relations in Market Networks. Ph.D. Thesis, University of Kentucky, Karasa Lexington, Kenya. 
Igene, J. A. (2008). Cattle Slaughter and Meat Supply in Maiduguri, Borno State in Nigeria. Journal of Animal Production, 4(2).

Institut National de la Statistique [INS]. (2013). Annuaire Statistique du Cameroun, Edition 2013, Yaoundé: INS. Retrieved 18 January 2015, from www.stat.cm/downloads/annuaire/2013/Annuaire_statistique_2013.pdf

Iya, I. B. (2008). An Analysis of the Effects of Cross-border Cattle Trade on the Economy of Adamawa State, Nigeria. ADSU Journal of Social and Developmental Studies, 2(1).

Macedo, K. (1987). The Demand for Foreign Exchange and its Effects on Cross-border Trade in Nigeria and Niger. Regional Bullion of Cross-border Trade Quarterly Journal, 7, Cotonou: LARES.

Marin, D., \& Verdier, T. (2014). Corporate Hierarchies and International Trade: Theory and Evidence, Munich. $\begin{array}{lllll}\text { Retrieved } 20 & \text { January } & \text { 2015, from }\end{array}$ www.iwb.vwl.uni-muenchen.de/forschung/.../ver_marin/.../powermarkup37-marin.pdf

Mayer, T., Melitz, M., \& Ottaviano, G. (2011). Market Size, Competition and the Product Mix of Exporters, CEPII Working Paper 2011-11, France. Retrieved 20 January 2015, from www.cepii.fr/PDF_PUB/wp/2011/wp2011-11.pdf

Mukherjee, S., \& Benson, T. (2003). The Determinants of Welfare in Malawi, 1998. World Development, 31(2), 339-358.

Mwaniki, J. (n.d). The Impact of Informal Cross-Border Trade on Regional in SADC and Implications for Wealth Creation, $\quad$ IRED-ESA. $\quad$ Retrieved 20 January 2015 , from www.sarpn.org/documents/d0001002/CFA-Mwaniki_CORN.pdf

National Bureau of Statistics [NBS]. (2010). Annual Abstract of Statistics 2010, Abuja: NBS. Retrieved 11 February 2015, from http:www.nigerianstat.gov.ng/pages/download/71

National Population Commission [NPC]. (2006). 2006 Population and Housing Census of the Federal Republic of Nigeria: National and State and Housing Tables, Priority Tables, (Volume1), Abuja: NPC. Retrieved 11 February 2015, from http://www.population.gov.ng/images/Priority\%20Tables\%20Volume\%20I-update.pdf

Nduru, M. R. (2004). Women who engage in Transactional Sex and Mobile Population in Africa. Academy for Educational Development.

Nkendah, R. (2010). The Informal Cross-border Trade of Agricultural Commodities between Cameroon and its CEMAC's Neighbours. A Paper for the NSF/AERC/IGC Conference, Mombassa, Kenya, December 4. Retrieved 20 January 2015, from www.theigc.org/wp-content/uploads/2014/08/nkendah.pdf

Okojie, C. E. E. (2002). Gender and Education as Determinants of Poverty Nigerian Households, WIDER Discussion Paper 2002/37, Helsinki: World Institute for Development Economics Research (WIDER) of the United Nations University.

Perberdy, S. (2002). Hurdles to Trade? South Africa's Immigration Policy and Informal Sector Cross-border Traders in the SADC. Paper Presented At Workshop on Regional Integration, Poverty and South Africa's Proposed Migration Policy, Pretoria.

Sa'ad, A. (1979). The Development of Yola Town. A Paper Presented at Mahmud Ribadu Square, Yola Gongola State.

Siddiqui, R. (2001). Gender Dimensions of Poverty in Pakistan. A Paper Presented at the Asia and Pacific Forum on Poverty: Reforming Policies and Institutions for Poverty Reduction, Manila: Asian Development Bank (ADB).

Thom, D. J. (1971). The Niger and Nigeria Border Laws: Politico-geographical Analysis Boundary Influence over the Hausas. Unpublished Ph.D. Thesis, Michigan State Ann Arbor.

Uche, E. O., Oumar, S. B., \& Gazali, K.A.Y. (2003). The Impact of Informal Livestock Trade between Borno and Adamawa States of Nigeria and the Far-north Province of Cameroon. Journal of Social and Management Sciences, $8(1)$.

Uyenuga, I. (1993). Livestock Industry in the Nigerian Economy. A Paper Presented at Veterinary Medical Students' Symposium at the University of Maiduguri, August, 28, Maiduguri.

Winston, S.A. (2009). The Role of Informal Cross-border Trade in Myanmar, Asia Paper, Sweden: Institute for Security and Development Policy (ISDP). Retrieved 11 February 2015, from http://www.isdp.eu/images/stories/isdp-main-pdf/2009_set-aung_the-role-of-informal-cross-border-trade.pdf

World Bank. (2001). World Development Report 2000/2001: Attacking Poverty, New York: Oxford University Press. $\begin{array}{lllll}\text { Retrieved } & 11 & \text { February } & \text { 2015, from }\end{array}$ http://www.ssc.wisc.edu/ walker/wp/wp-content/uploads/2012/10/wdr2001.pdf 


\section{Appendices: Contingency Tables}

Appendix A. Contingency table of actual scores

\begin{tabular}{lccc}
\hline & \multicolumn{2}{c}{ Responses } & Total \\
\cline { 2 - 4 } Market & Yes & No & \\
Adoumri & 20 & 0 & 20 \\
Garoua & 18 & 2 & 20 \\
Mokolo & 20 & 0 & 20 \\
Ngaoundéré & 17 & 3 & 20 \\
Ganye & 19 & 1 & 20 \\
Konkol & 20 & 0 & 20 \\
Madagali & 20 & 0 & 20 \\
Mubi & 19 & 1 & 20 \\
Ngurore & 20 & 0 & 20 \\
Shigari & 15 & 5 & 20 \\
\hline Total & 188 & 12 & 200 \\
\hline
\end{tabular}

Appendix B. Contingency table of theoretical scores

\begin{tabular}{lccc}
\hline & \multicolumn{2}{c}{ Responses } & Total \\
\cline { 2 - 3 } Market & Yes & No & \\
Adoumri & 18.8 & 1.2 & 20 \\
Garoua & 18.8 & 1.2 & 20 \\
Mokolo & 18.8 & 1.2 & 20 \\
Ngaoundéré & 18.8 & 1.2 & 20 \\
Ganye & 18.8 & 1.2 & 20 \\
Konkol & 18.8 & 1.2 & 20 \\
Madagali & 18.8 & 1.2 & 20 \\
Mubi & 18.8 & 1.2 & 20 \\
Ngurore & 18.8 & 1.2 & 20 \\
Shigari & 18.8 & 1.2 & 20 \\
\hline Total & 188 & 12 & 200 \\
\hline
\end{tabular}

Appendix C. Chi-square computation table

\begin{tabular}{ccccc}
\hline A (Actual Scores) & $\mathrm{T}$ (Theoretical Scores) & $\mathrm{A}-\mathrm{T}$ & $(\mathrm{A}-\mathrm{T})^{2}$ & $(\mathrm{~A}-\mathrm{T})^{2} \div \mathrm{T}$ \\
\hline 20 & 18.8 & 1.2 & 1.44 & 0.076596 \\
18 & 18.8 & -0.8 & 0.64 & 0.034043 \\
20 & 18.8 & 1.2 & 1.44 & 0.076596 \\
17 & 18.8 & -1.8 & 3.24 & 0.17234 \\
19 & 18.8 & 0.2 & 0.04 & 0.002128 \\
20 & 18.8 & 1.2 & 1.44 & 0.076596 \\
20 & 18.8 & 1.2 & 1.44 & 0.076596 \\
19 & 18.8 & 0.2 & 0.04 & 0.002128 \\
20 & 18.8 & 1.2 & 1.44 & 0.076596 \\
15 & 18.8 & -3.8 & 14.44 & 0.768085 \\
0 & 1.2 & -1.2 & 1.44 & 1.2 \\
2 & 1.2 & 0.8 & 0.64 & 0.533333 \\
0 & 1.2 & -1.2 & 1.44 & 1.2 \\
3 & 1.2 & 1.8 & 3.24 & 2.7 \\
1 & 1.2 & -0.2 & 0.04 & 0.033333 \\
0 & 1.2 & -1.2 & 1.44 & 1.2 \\
0 & 1.2 & -1.2 & 1.44 & 1.2 \\
1 & 1.2 & -0.2 & 0.04 & 0.033333 \\
0 & 1.2 & -1.2 & 1.44 & 1.2 \\
5 & 1.2 & 3.8 & 14.44 & 12.03333 \\
\hline- & - & - & - & $\mathrm{X}_{\mathrm{s}}^{2}-$ Stat $=22.69504$ \\
\hline
\end{tabular}

